\title{
Change in tropical rocky shore communities due to an alien coral invasion
}

\author{
B. G. Lages ${ }^{1}$, B. G. Fleury ${ }^{2}$, C. Menegola ${ }^{3}$, J. C. Creed ${ }^{2, *}$ \\ ${ }^{1}$ Programa de Pós-Graduação em Ecologia e Evolução and ${ }^{2}$ Departamento de Ecologia, Instituto de Biologia Roberto \\ Alcântara Gomes, Universidade do Estado do Rio de Janeiro - UERJ, CEP 20559-900 Rio de Janeiro, RJ, Brasil \\ ${ }^{3}$ Departamento de Zoologia, Instituto de Biologia, Universidade Federal da Bahia, CEP 40170-290 Salvador, BA, Brasil
}

\begin{abstract}
To determine how benthic, tropical, rocky shore communities were affected by the invasive coral species Tubastraea coccinea and T. tagusensis, 8 sites were studied during 2 yr on rocky shores in the southwest Atlantic Ocean (Brazil) by using both fixed and random sampling techniques. Overall, mean cover of $T$. tagusensis was $0.7 \%$ and $T$. coccinea was $0.4 \%$, (the eleventh and sixteenth most abundant taxa, respectively, throughout the sites). Forty-two major space occupying taxa were registered. In fixed quadrats there was a $76.6 \%$ increase per year in density of Tubastraea spp. over the study period. For percent cover no significant difference in cover over time was detected for T. coccinea, but for T. tagusensis and overall (both species) cover increased significantly. The random quadrats data showed subtle differences from the fixed quadrats. There was an increase in density of Tubastraea spp. through time $(67.8 \%$ per year over the study period). In random samples the density of $T$. coccinea increased during the study but that of T. tagusensis did not. The cover of both corals also increased over time. The sites where Tubastraea spp. were most abundant possessed higher diversity, evenness and richness of species. Sites where Tubastraea was present tended to group in ordination. The presence of Tubastraea in the communities caused a mean dissimilarity of $4.8 \%$ in the invaded communities. A strong positive relationship between invader cover and change in community structure was found, which suggested complete $(100 \%)$ community dissimilarity at an invader cover of $45 \%$. The negative effects are sufficient to disturb the native benthic communities throughout the tropical Atlantic Ocean.
\end{abstract}

KEY WORDS: Benthos - Community structure - Diversity · Invasive species · Scleractinian coral · Tubastraea Resale or republication not permitted without written consent of the publisher

\section{INTRODUCTION}

Owing to increased merchant shipping at the close of the 20th century, biological invasions of marine ecosystems have become common (Carlton 1996). Exotic invasive species threaten native biodiversity (Cariton \& Geller 1993, Wilcove et al. 1998), alter ecosystem structure and function (Mack et al. 2000) and annually cost billions of dollars in damage to coastal regions of the world (Pimentel et al. 2005). The successful establishment of alien organisms is, in large part, due to the transport and release of species from ships' ballast water, incrustations on ships and floating platforms and from sediments (Cariton \& Geller 1993, Carlton 1996). Regardless of the mechanisms involved, invasion by exotic species has lead to hypotheses of positive feedbacks of the effects of this increasing number of exotic species that could facilitate additional invasions and lead to invasion 'meltdown' (Simberloff \& Halle 1999).

Until recently the transformations of native communities caused by the establishment and spread of 
invasive species have been poorly understood for most systems (Grosholz 2002). This is probably because the study of invasions in coastal systems and habitats began only 25 yr ago (Carlton 1985, 1987, Grosholz 2002). In the past $10 \mathrm{yr}$, there has been increased interest in the biological invasion of marine communities because of highly publicized impacts of some organisms (Mills et al. 1994). This interest has translated into a rapidly accumulating literature that addresses both the ecological and evolutionary consequences of invasions, which has significantly contributed to our understanding of invasions in coastal systems (Grosholz 2002).

Most coral species are considered to be extremely sensitive to environmental change and therefore are thought to not survive transport. Only a few corals have been reported as alien species: the scleractinian coral Oculina patagonica from the southwest Atlantic Ocean has invaded the Mediterranean Sea (Fine et al. 2001, Sartoretto et al. 2008); the Indo-Pacific mushroom coral Fungia scutaria has been reported as established (alive for $20 \mathrm{yr}$ and actively budding) in Jamaica (Bush et al. 2004); the octocoral Carijoa riisei from the Caribbean Sea and southwest Atlantic Ocean has invaded Hawaii (Grigg 2003); the octocoral Chromonephthea braziliensis, of unknown origin, has become established in Brazil (Lages et al. 2006, reported as Stereonephthya aff. curvata). There are, therefore, only few studies dealing with the invasion of coral species in coastal systems (Fenner \& Banks 2004, Kahng \& Grigg 2005, Paula \& Creed 2005, Lages et al. 2006, Sartoretto et al. 2008). However, the ahermatypic coral Tubastraea (Scleractinia: Dendrophylliidae) is nonindigenous to the Atlantic Ocean and was probably brought to Brazilian waters in the late 1980s (Castro \& Pires 2001) by oil and gas platforms. Two species, Tubastraea coccinea Lesson, 1829 and Tubastraea tagusensis Wells, 1982, have been identified as alien and invasive to the rocky shores of southeast Brazil (Paula \& Creed 2004). These azooxanthellate species have become established and have now invaded shallow subtidal rocky shores along $900 \mathrm{~km}$ of the southeast Atlantic coast in 5 distinct regions. At the principal region at Ilha Grande Bay, Paula \& Creed (2005) demonstrated that Tubastraea spp. were well established at most sites, with mean densities of 1 to 20 colonies $\mathrm{m}^{-2}$, though occasionally $>200$ colonies $\mathrm{m}^{-2}$ were found, which indicates a gregarious spatial distribution and an invasive trait. Tubastraea has been described as an invasive coral affecting other endemic species by competition for space (Ferreira
2003, Paula \& Creed 2005, Creed 2006), although the changes in community structure or function of native communities caused by Tubastraea spp. have not previously been studied.

The biological invasion of Tubastraea spp. is not restricted to the southwest Atlantic region. Sammarco et al. (2010) recently reviewed the history and potential of invasion by this genus throughout the Atlantic Ocean, Caribbean Sea and Gulf of Mexico. Because these corals are now established, are under active range expansion and apparently have negative effects on the local tropical rocky shore benthos, we took the opportunity that this 'natural experiment' provided to: (1) compare the structure of invaded and natural communities to identify changes in community structure, and (2) investigate temporal change in the abundance of corals over a 2 yr period to determine the direction and speed of community structure changes.

\section{MATERIALS AND METHODS}

\section{Study sites}

Ilha Grande is located in the south of Rio de Janeiro state in Brazil $\left(22^{\circ} 50^{\prime}\right.$ to $23^{\circ} 20^{\prime} \mathrm{S}, 44^{\circ} 00^{\prime}$ to $\left.44^{\circ} 45^{\prime} \mathrm{W}\right)$. Between the island and the continent a channel (the Canal Central) is used intensively as a shipping lane and receives international shipping traffic and oil platforms in transit for repair (Fig. 1). Ilha Grande Bay possesses some marine protected areas, but the fauna and flora remain susceptible owing to the effect of many human activities.

The 8 sites studied were located on the continental side of Ilha Grande along the Canal Central, on shallow subtidal rocky reefs extending from the intertidal to the sandy plain at 4 to $7 \mathrm{~m}$ depth. During the year, the temperature of the tropical surface waters in Ilha Grande varies from 21 to $32^{\circ} \mathrm{C}$ during the wet summer and dry winter seasons.

Four paired sites were selected based on previously reported differences in the relative abundance of Tubastraea spp. (Paula \& Creed 2005): (1) no Tubas-

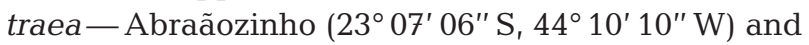
Crena $\left(23^{\circ} 08^{\prime} 08^{\prime \prime} \mathrm{S}, 4^{\circ} 09^{\prime} 25^{\prime \prime} \mathrm{W}\right)$; (2) low abun-

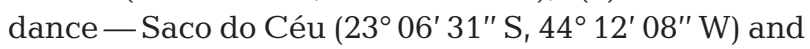

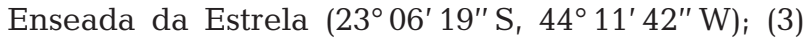
medium abundance - Ponta do Barreto $\left(23^{\circ} 06^{\prime} 08^{\prime \prime} \mathrm{S}\right.$, $\left.44^{\circ} 11^{\prime} 31^{\prime \prime} \mathrm{W}\right)$ and Guaxumã (230.5 $50^{\prime \prime} \mathrm{S}$, $\left.44^{\circ} 12^{\prime} 13^{\prime \prime} \mathrm{W}\right) ;(4)$ high abundance - Ilha dos Macacos $\left(23^{\circ} 04^{\prime} 36^{\prime \prime} \mathrm{S}, 44^{\circ} 13^{\prime} 47^{\prime \prime} \mathrm{W}\right)$ and Ilha da Aroeira $\left(23^{\circ} 04^{\prime} 40^{\prime \prime} \mathrm{S}, 44^{\circ} 14^{\prime} 23^{\prime \prime} \mathrm{W}\right)$. 


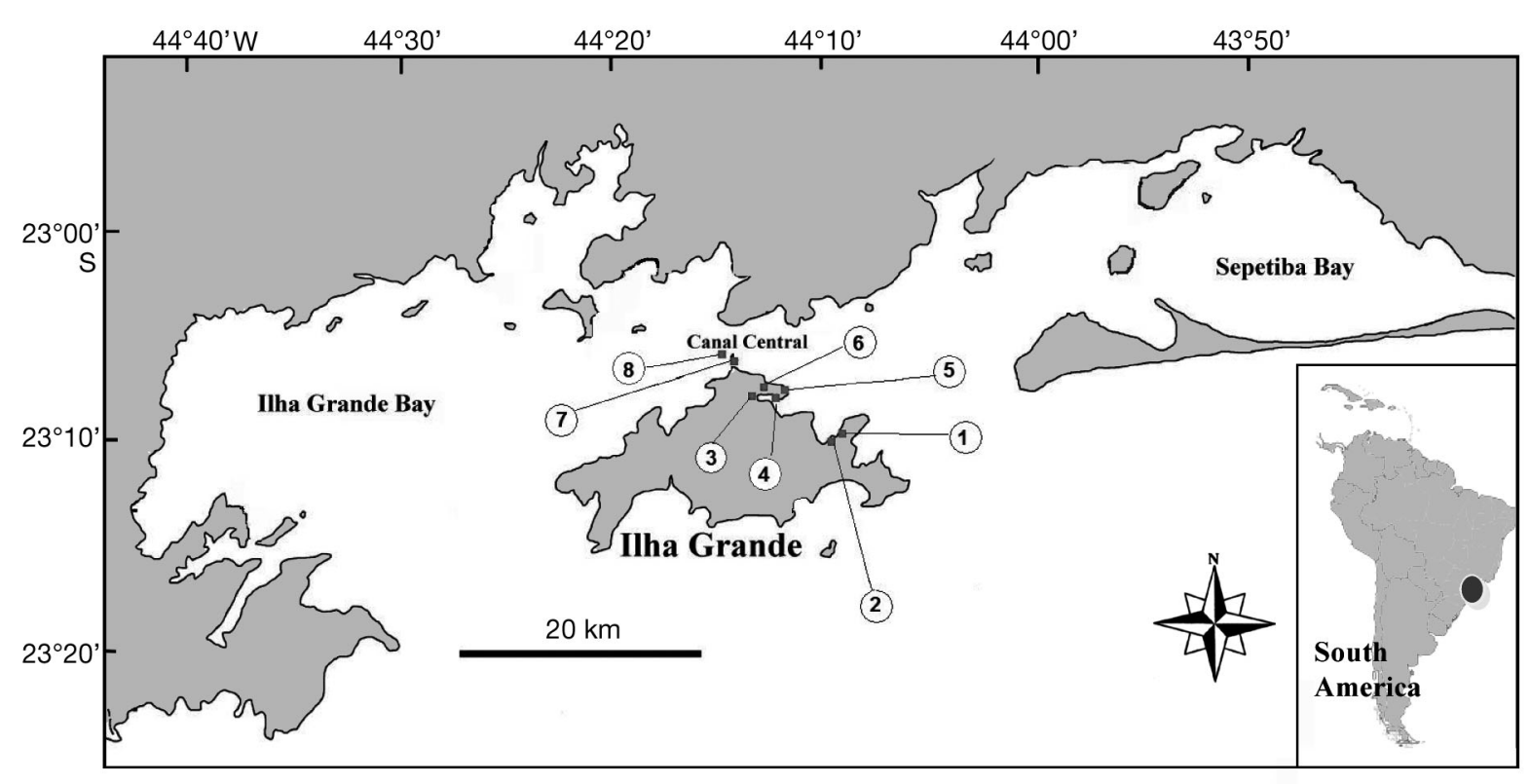

Fig. 1. Study sites at Ilha Grande Bay, Brazil: (1) Abraãozinho; (2) Crena; (3) Saco do Céu; (4) Enseada da Estrela; (5) Ponta do Barreto; (6) Guaxumã; (7) Ilha dos Macacos; (8) Ilha da Aroeira

\section{Data collection}

Percent cover of the sessile macrobenthic species was measured on 4 occasions, in February (summer) and in July (winter) during 2005 and 2006. This was achieved by using SCUBA and $0.25 \mathrm{~m}^{2}$ quadrats, the community sampling unit, which were placed onto permanently marked, randomly positioned $50 \mathrm{~m}$ transects previously placed at each site parallel to the coast in 1 to $3 \mathrm{~m}$, a depth at which Tubastraea spp., when present, is most abundant. We employed 15 fixed position and 15 randomly positioned quadrats. We used a mixed approach of random quadrats to allow statistical independence and fixed position (but randomly initially determined) quadrats to test whether fixed quadrats maximized sensitivity to temporal change. Similar to the method used by Oigman-Pszczol et al. (2004), divers estimated cover in each quadrat by noting the major space-occupying taxon or functional group in each of $25,10 \times 10 \mathrm{~cm}$ subquadrats. This method focused attention on the dominant space-occupying organisms in the community that could be identified in situ, although samples of sponges were collected and identified with standard techniques. The density of the 2 alien coral species was estimated by counting individuals or colonies in each quadrat. The 2 metrics were complementary because it was desirable to detect new invasions of recent coral recruits, although they are very small and would not be detected by area occupation.

\section{Data analysis}

Density and percentage cover of Tubastraea spp. were compared over time and between sites with ANOVA (SPSS for Windows). The percentage cover data were arcsine transformed and density data were square root transformed. Complementary Tukey's tests were performed after ANOVA to identify which sites or times were responsible for differences in density or percentage cover. For fixed quadrat analyses we used repeated measures ANOVA. For these variables sites where Tubastraea was not detected during the study period were excluded from analyses as all zero values are contrary to the assumptions of the analysis. To describe differences in benthic community structure between sites we calculated the overall richness of species $(S)$, Shannon-Wiener diversity index $\left(H^{\prime}\right)$ and Pielou's species evenness index $\left(J^{\prime}\right)$ (Magurran 1988) for each site, using means of times. For multivariate community analysis we used the Primer 5 package (Primer-E) to generate Bray-Curtis similarity coefficients from standardized 4 th root transformed transect means that were compared with cluster analyses and multi-dimensional scaling (MDS). Differences between groups were tested with analysis of similarities (ANOSIM).

To visualize and quantify the possible change in community structure due to the invasive corals we used 2 methods: (1) comparison of invaded versus noninvaded communities; (2) repeat analyses on 
community cover data in which Tubastraea had been artificially removed from the data set and means proportionally redistributed. The second method assumed that all native taxa were negatively affected proportionally by the presence of the invasive corals. We then recalculated and compared the community indices (see above in Data analysis), compared these communities with cluster analysis and MDS and used a polynomial regression as a predictive tool to examine the community change (as percent reduction in similarity) as a function of cover of the invasive corals (Tubastraea spp. pooled). The rationale for this pooling and other analyses presented at the genus level was that both species have invaded the region together and are so intimately linked that they are nearly always found growing together in mixed species populations, often fused into 2-species 'colonies'.

\section{RESULTS}

\section{Population density and cover of Tubastraea}

In the fixed quadrats Tubastraea was found in 5 of the 8 sites (not found at Abraãozinho, Crena or Guaxumã). In general, the data showed an increase of $76.6 \%$ per year in colony population density of Tubastraea spp. over the study period, which was statistically significant (ANOVA: $F=14.714, \mathrm{p} \leq$ 0.001), and the Macacos and Aroeira sites had higher densities than did Saco do Céu, Estrela and Barreto (ANOVA: $F=23.749, \mathrm{p} \leq 0.001$; Tukey's test: $\alpha<0.05$ ) (Fig. 2). The density of T. coccinea at the sites Estrela and Barreto was lower than at Macacos and Aroeira (ANOVA: $F=19.32, \mathrm{p} \leq 0.001$; Tukey's test: $\alpha<0.05$ )

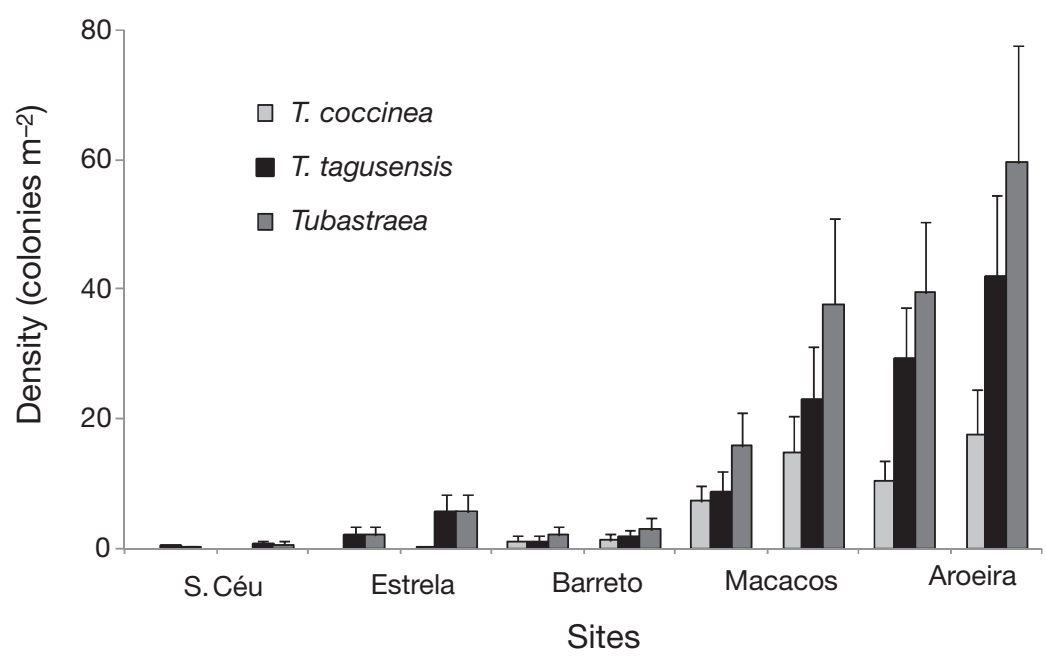

Fig. 2. Tubastraea spp. Density of colonies of the genus and each species in fixed quadrats at 6 sites over 2 yr (2005 and 2006), means + SE
(Fig. 2). For T. tagusensis there were also significant increases in density over time (ANOVA: $F=19.352$, $\mathrm{p} \leq 0.001$ ) and the Aroeira site had higher densities than Macacos, Barreto, Estrela and Saco do Céu sites (ANOVA: $F=23.551, \mathrm{p} \leq 0.001$; Tukey's test: $\alpha<0.05$ ) (Fig. 2). Interactions between site and time were not statistically significant for $T$. coccinea (ANOVA: $F=$ 1.879, $\mathrm{p}=0.144$ ), T. tagusensis (ANOVA: $F=1.921$, $\mathrm{p}=0.117$ ) or Tubastraea spp. (ANOVA: $F=1.975, \mathrm{p}=$ $0.108)$.

The percent cover data of Tubastraea coccinea for fixed quadrats showed a statistically significant difference between sites (ANOVA: $F=4.093, \mathrm{p}=0.02$ ) as percent cover of this species was lower at Saco do Céu and Barreto than at Aroeira (Fig. 3). For Tubastraea tagusensis a similar pattern was found (Saco do Céu and Barreto, but different from Aroeira, ANOVA: $F=3.718, \mathrm{p}=0.004)$. The overall cover of Tubastraea was lower at Saco do Céu, Estrela and Barreto than Aroeira (Fig. 3), (ANOVA: $F=4.623, p=0.001$ ). Although no significant difference in cover over time was detected for $T$. coccinea ( $p=0.199$ ), for $T$. tagusensis and overall (both species) cover increased significantly (ANOVA: $F=4.213, \mathrm{p}=0.043$ and $F=$ 4.865, $\mathrm{p}=0.030$, respectively) (Fig. 3).

The random quadrats data showed subtle differences from the fixed quadrats. Tubastraea was found in 7 of the 8 sites (not at Abraãozinho). Overall there was an increase in the colony population density of Tubastraea throughout the period at a rate of $67.8 \%$ per year. There was a statistically significant increase in density of Tubastraea coccinea over the period of the study (ANOVA: $F=6.507, \mathrm{p}=0.011$ ) and between sites (ANOVA: $F=34.937, \mathrm{p} \leq 0.001$ ) (Fig. 4). For T. tagusensis there was also a significant difference between sites (ANOVA: $F=34.734$, $\mathrm{p} \leq 0.001$ ) as the density was very low at Crena, but no significant difference between years was found ( $p=0.119$ ) (Fig. 4). Overall Tubastraea spp. showed a statistically significant difference in density between sites (ANOVA: $F=37.301, \mathrm{p} \leq 0.001$ ) and between years (ANOVA: $F=5.274, \mathrm{p}=$ 0.022) (Fig. 4). No significant interactions between time and site were detected.

In terms of percentage cover there was statistically significant difference in cover of Tubastraea coccinea between sites (ANOVA: $F=5.241, \mathrm{p}<$ $0.001)$ and increase between years (ANOVA: $F=3.957, \mathrm{p}<0.047$ ) 


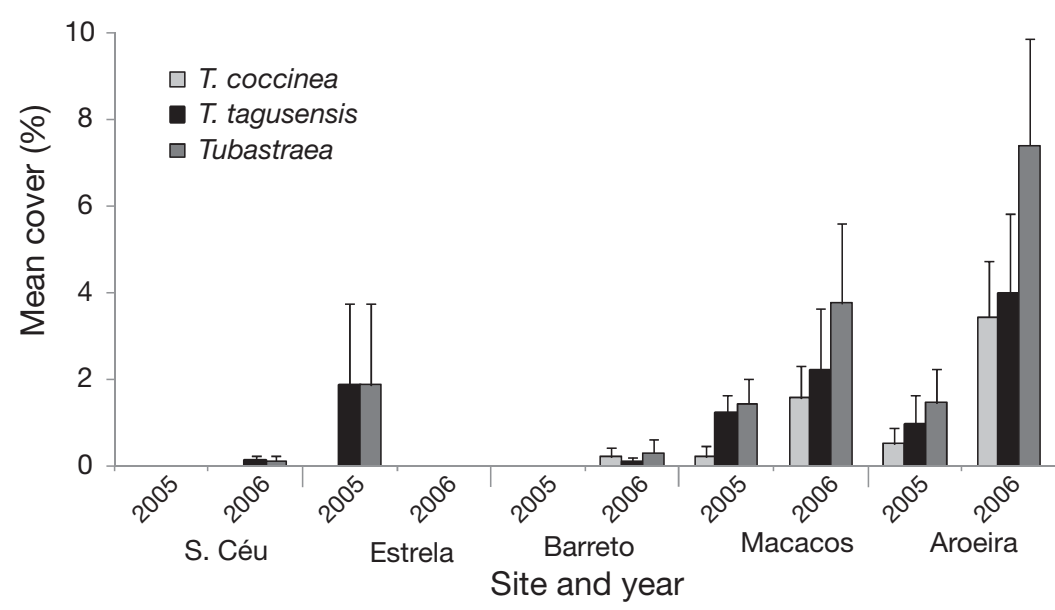

Fig. 3. Tubastraea spp. Cover of the genus and each species in fixed quadrats at 5 sites over 2 yr (2005 and 2006), means + SE

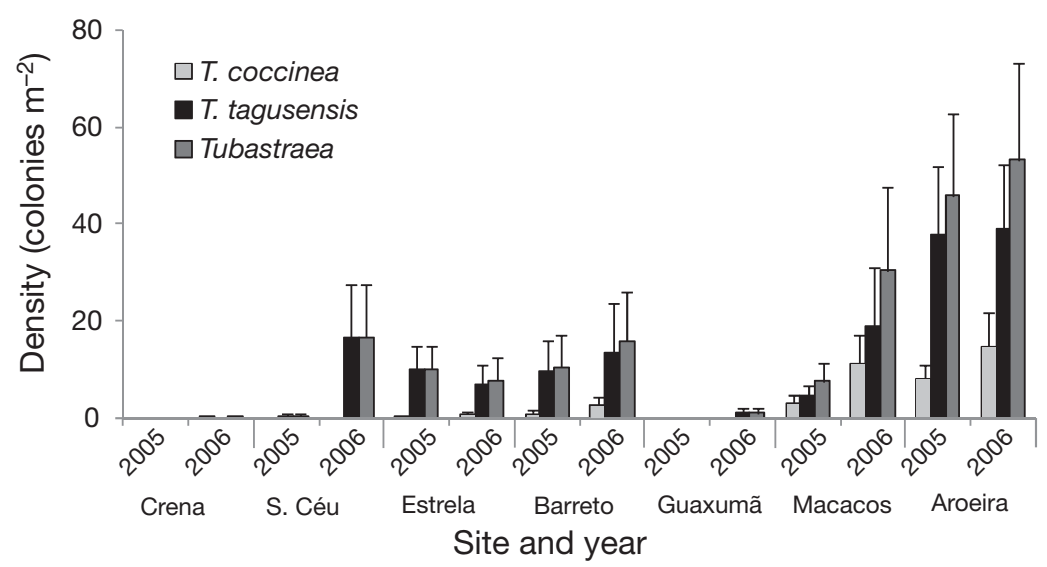

Fig. 4. Tubastraea spp. Density of colonies of the genus and each species in random quadrats at 6 sites over 2 yr (2005 and 2006), means + SE

the red alga Falkenbergia sp., the sponge Desmapsamma anchorata, the zoanthid Palythoa caribaeorum and the coral Mussismilia hispida were the most frequent space-occupying taxa found at all sites. Considering all sites, the ranking of the most abundant taxa was: $P$. caribaeorum (a zoanthid with $47.2 \%$ cover, on average, at all sites), turf algae $(28.7 \%)$ and Falkenbergia sp. (4.2\%) (Table 1).

Richness of the main space-occupying organisms (see Methods and materials) per site varied from 13 to 23 taxa (Table 2). The diversity of benthos between the 8 sites studied was quite variable; the sites with more diversity were Crena, Saco do Céu and Aroeira and those with less diversity were Abraãozinho and Estrela (Table 2). In general the sites where Tubastraea spp. was present and most abundant possessed higher diversity, evenness and richness of species when compared with the same sites without these exotic corals (Aroeira and Macacos, Table 2).

As the results of community analysis were similar for both methods of quadrat placement, only the random quadrat results are presented. The nonmetric, multidimensional scaling (MDS) of transect (site) means demon-

(Fig. 5a). There was also a significant difference between sites and over time for $T$. tagusensis (ANOVA: $F=5.008, \mathrm{p}<0.001$ and $F=4.414, \mathrm{p}=$ 0.005, respectively) (Fig. 5b) and for Tubastraea overall (ANOVA: $F=6.276, \mathrm{p}<0.001$ and $F=4.685, \mathrm{p}=$ 0.003, respectively) (Fig. 5c). No statistically significant interactions between sites and time were found for either species.

\section{Community change}

The overall composition of the benthic communities at Ilha Grande is summarized in Table 1. Overall, mean cover of Tubastraea tagusensis was $0.65 \%$ and T. coccinea was $0.37 \%$, being the eleventh and sixteenth most abundant taxa, respectively, throughout the sites. For all benthic communities we found a total of 42 major space-occupying taxa of algae and invertebrates. Crustose calcareous algae, turf algae, strated that communities with and without Tubastraea spp. cluster nearly separately in the MDS; an ANOSIM indicated that differences between these 2 types of communities are statistically significant (Fig. 6, top left, Stress 0.14; ANOSIM: R = 0.181, p = 0.001). One point with Tubastraea (L3T4, Saco do Céu in July 2006) did not form part of the main group, probably because this site began to be invaded at the end of the study. Additionally, cluster and MDS analyses performed to compare and quantify the influence of the presence of Tubastraea spp. in the communities at invaded sites (Figs. $7 \& 8$, respectively) revealed that the presence of Tubastraea in the communities caused a mean $4.81 \%$ dissimilarity (minimum 1\%, maximum $11.09 \%$ ) in the invaded communities when compared with standardized communities where Tubastraea spp. had been excluded. ANOSIM confirmed a significant effect of the presence of Tubastraea spp. in the community organization $(\mathrm{R}=0.206, \mathrm{p}=0.001)$. A strong positive relation- 


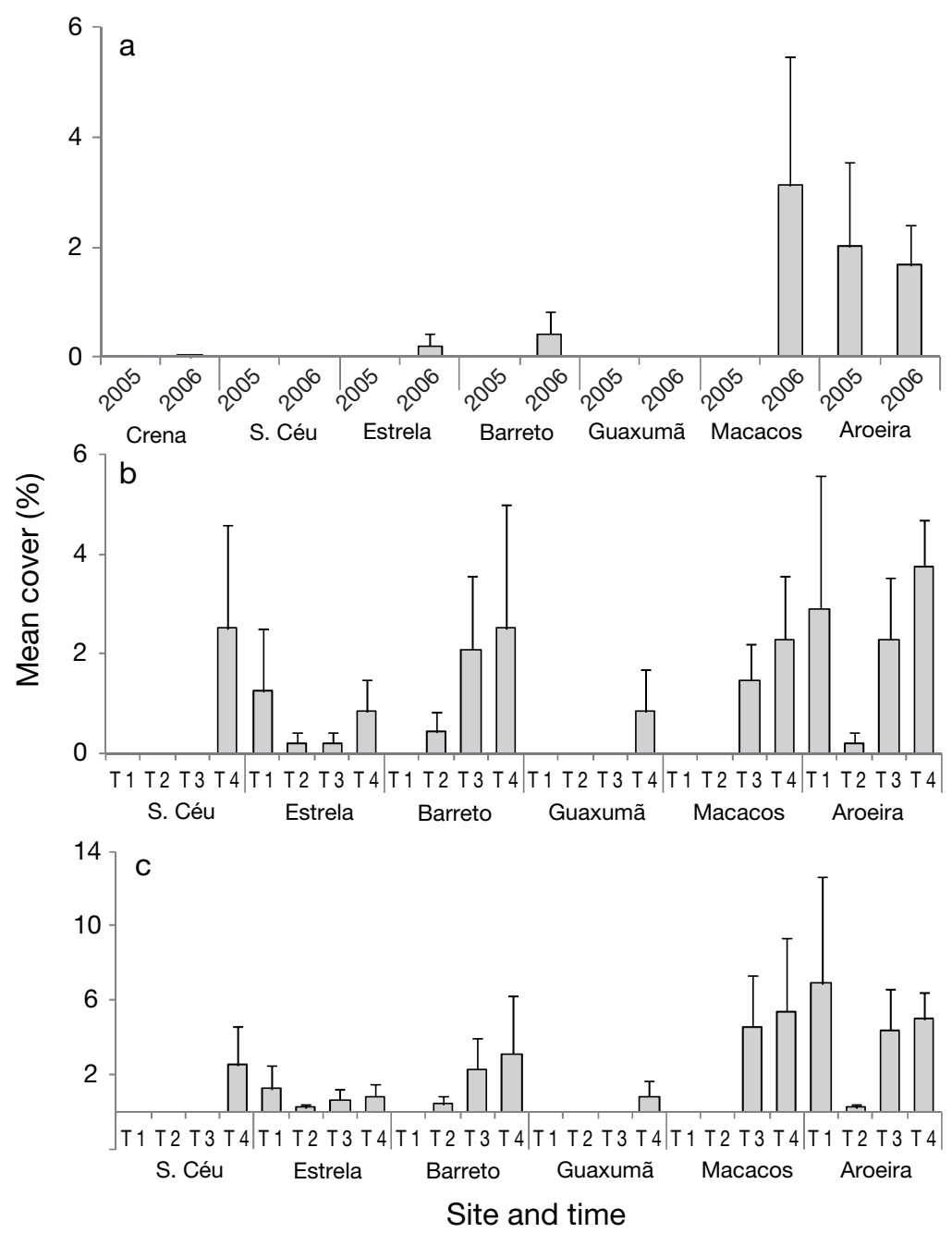

Fig. 5. Tubastraea spp. (a) Percent cover of Tubastraea coccinea over 2 yr in random quadrats at 7 sites; (b) percent cover of Tubastraea tagusensis and (c) Tubastraea spp. in random quadrats at 4 times over 2 yr (2005 and 2006). Means + SE. T1: January 2005; T2: July 2005; T3: January 2006; T4: July 2006

ship (regression $\mathrm{R}^{2}=0.93, \mathrm{p}<0.001$ ) between invader cover (Tubastraea spp.) and change in community structure was found: \% community dissimilarity = $2.24 \times \%$ cover with Tubastraea spp. This would suggest complete $(100 \%)$ community dissimilarity at an invader cover of $45 \%$.

\section{DISCUSSION}

The shores of Ilha Grande are presently being invaded by 2 species of Tubastraea. To date, no previous studies have quantified such basic information such as rates of recruitment, the dynamics of space occupation or the influence of the presence of these invasive corals on the structure of the native commu- nities. The consolidation of $T$. tagusensis was faster than $T$. coccinea even though the latter also increased significantly in their density and abundance during the study. As well as expanding their range throughout the region and beyond (see Mantelatto et al. 2011) they have reached extremely high densities and cover at some sites. Castro et al. (1999) had previously (1993) studied the distribution of Cnidaria at Ilha Grande, including some of the same locations sampled in the present study, but did not register the highly visible Tubastraea spp.

Tubastraea spp. increased overall by $72 \%$ in cover over the study period. Additionally, the average density of Tubastraea spp. was 62 colonies $\mathrm{m}^{-2}$, which is very high, even when considering mean values of overall density of all coral species on coral reefs (see Oigman-Pszczol \& Creed 2004). During the period, Tubastraea was found in 5 (fixed quadrats) and 7 (random quadrats) of 8 sites, and its density increased significantly through time. This suggests that the 2 azooxanthellate corals are competitively dominant; they are known to reduce or exclude the native scleractinian coral Mussismilia hispida, which is endemic to Brazil (Creed 2006).

The 'positive' (statistical) effect of Tubastraea seen here in terms of increase in richness, evenness and diversity of the benthos due to the presence of this exotic coral along the study period is probably due to 2 reasons. (1) Scleractinian corals are ecosystem engineers that create microhabitats and modify nearby physical and chemical processes because they are principle architects (Jones et al. 1997, Idjadi \& Edmunds 2006). (2) An invading species represents, immediately, an increase in richness (presence) and diversity (as it establishes). Ilha Grande Bay is a region with a high diversity of benthos (groups such as macroalgae and cnidarians, Creed et al. 2007) when compared with other regions of the Brazilian coastline. Ongoing studies also show remarkable species richness of sponges (C. Menegola pers. obs.). A wide array of benthic organisms such as turf algae, crustose calcareous algae, Falkenbergia sp., Palythoa caribaeorum, Mussismilia his- 
Table 1. Major space-occupying taxa, their mean frequency of occurrence (\%) (proportion of sites where the taxon was registered) and cover percent (mean \pm SE) amongst the 8 study sites (all times pooled) at Ilha Grande Bay

\begin{tabular}{|c|c|c|}
\hline $\begin{array}{r}\text { Fre } \\
\text { oc }\end{array}$ & $\begin{array}{l}\text { equency of } \\
\text { ccurrence }\end{array}$ & $\begin{array}{c}\text { Cover }( \pm \mathrm{SE}) \\
(\%)\end{array}$ \\
\hline \multicolumn{3}{|l|}{ Algae } \\
\hline Chlorophyta spp. & 62.5 & $0.49( \pm 0.25)$ \\
\hline \multicolumn{3}{|l|}{ Heterokontophyta } \\
\hline Dictyota spp. & 37.5 & $0.18( \pm 0.12)$ \\
\hline Padina gymnospora (Kützing) Sonder & 37.5 & $1.09( \pm 0.94)$ \\
\hline Sargassum spp. & 37.5 & $1.90( \pm 1.57)$ \\
\hline Heterokontophyta sp. 1 & 50 & $0.27( \pm 0.13)$ \\
\hline Ectocarpus spp. & 12.5 & $0.01( \pm 0.01)$ \\
\hline \multicolumn{3}{|l|}{ Rhodophyta } \\
\hline $\begin{array}{l}\text { Galaxaura marginata (Ellis \& Solander) } \\
\text { J. V. Lamouroux }\end{array}$ & 37.5 & $0.64( \pm 0.49)$ \\
\hline Laurencia cf. obtusa (Hudson) J. V. Lamouroux & 25 & $0.04( \pm 0.02)$ \\
\hline Hypnea spinella (C. Agardh) Kützing & 25 & $0.16( \pm 0.13)$ \\
\hline Acanthophora spicifera (M. Vahl) Børgesen & 37.5 & $0.04( \pm 0.02)$ \\
\hline \multicolumn{3}{|l|}{ Trevisan de Saint-Léon } \\
\hline Falkenbergia sp. & 100 & $4.25( \pm 1.08)$ \\
\hline Polysiphonia ferulacea Suhr ex J. Agardh & 37.5 & $0.34( \pm 0.22)$ \\
\hline Gelidium pusillum (Stackhouse) Le Jolis & 75 & $1.85( \pm 0.80)$ \\
\hline Crustose calcareous algae & 100 & $2.87( \pm 0.43)$ \\
\hline 'Turf algae' & 100 & $28.68( \pm 6.10)$ \\
\hline \multicolumn{3}{|l|}{ Porifera } \\
\hline Desmapsamma anchorata (Carter 1882) & 100 & $1.31( \pm 0.35)$ \\
\hline Dysidea janiae (Duchassaing \& Michelotti, 1864) & 4) 37.5 & $0.23( \pm 0.16)$ \\
\hline Mycale microsigmatosa Arndt, 1927 & 62.5 & $0.26( \pm 0.14)$ \\
\hline Mycale magniraphidifera van Soest, 1984 & 12.5 & $0.01( \pm 0.01)$ \\
\hline $\begin{array}{l}\text { Mycale escarlatei Hajdu, Zea, } \\
\text { Kielman \& Peixinho, } 1995\end{array}$ & 12.5 & $0.01( \pm 0.01)$ \\
\hline Iotrochota birotulata (Higgin, 1877) & 50 & $0.59( \pm 0.36)$ \\
\hline Haliclona melana Muricy \& Ribeiro, 1999 & 25 & $0.05( \pm 0.03)$ \\
\hline Tedania sp. & 25 & $0.03( \pm 0.03)$ \\
\hline Aplysina fulva (Pallas, 1766) & 12.5 & $0.01( \pm 0.01)$ \\
\hline Aplysilla rosea (Barrois, 1876) & 12.5 & $0.03( \pm 0.03)$ \\
\hline Porifera sp. 1 & 12.5 & $0.03( \pm 0.03)$ \\
\hline \multicolumn{3}{|l|}{ Cnidaria } \\
\hline $\begin{array}{l}\text { Palythoa caribaeorum } \\
\text { (Duchassaing \& Michelotti, 1860) }\end{array}$ & 100 & $47.21( \pm 8.08)$ \\
\hline Zoanthus sociatus Ellis \& Solander, 1786 & 50 & $0.55( \pm 0.37)$ \\
\hline Mussismilia hispida (Verrill, 1901) & 100 & $1.63( \pm 0.75)$ \\
\hline Tubastraea coccinea Lesson, 1829 & 37.5 & $0.37( \pm 0.25)$ \\
\hline Tubastraea tagusensis Wells, 1982. & 62.5 & $0.65( \pm 0.34)$ \\
\hline Carijoa riisei (Duchassaing \& Michelotti, 1860) & 25 & $0.08( \pm 0.06)$ \\
\hline Aiptasia pallida (Agassiz, 1864) & 62.5 & $3.47( \pm 2.74)$ \\
\hline Phyllactis praetexta (Couthouy in Dana, 1846) & 12.5 & $0.01( \pm 0.01)$ \\
\hline Annelida: Polychaeta & 12.5 & $0.06( \pm 0.06)$ \\
\hline Arthropoda: Crustacea: Thoracica & 12.5 & $0.28( \pm 0.28)$ \\
\hline \multicolumn{3}{|l|}{ Ectoprocta } \\
\hline Schizoporella spp. & 50 & $0.07( \pm 0.03)$ \\
\hline \multicolumn{3}{|l|}{ Urochordata } \\
\hline Didemnidae & 37.5 & $0.09( \pm 0.07)$ \\
\hline Didemnum spp. & 12.5 & $0.01( \pm 0.01)$ \\
\hline Phallusia nigra (Savigny, 1816) & 62.5 & $0.08( \pm 0.04)$ \\
\hline Ascidiacea, unidentified & 12.5 & $0.01( \pm 0.01)$ \\
\hline
\end{tabular}

pida and Desmapsamma anchorata occurred at all sites studied.

Although we present important baseline data, 2 outstanding questions were not addressed in this descriptive study. Firstly, were the communities at the different sites already different before the biological invasion occurred and do the differences found in communities simply reflect the susceptibility of different pre-established communities to the invaders? In southeast Brazil rocky shore communities are common although relatively little is known about the structure and function of tropical rocky shores in the southwest Atlantic Ocean (see Eston et al. 1986, Oigman-Pszczol et al. 2004, Ghilardi et al. 2008). For all sites, only 3 major space-occupying taxa covered $>80 \%$ of hard substrate at the studied depths: Palythoa caribeorum, turf algae and Falkenbergia sp. Villaça \& Pitombo (1997) also observed that $P$. caribaeorum was one of the most important cnidarians in the shallow water reefs of Abrolhos, Brazil. Oigman-Pszczol et al. (2004) found that turf algae and P. caribaeorum were most abundant taxa and represented 36 and $23 \%$, respectively, of cover in a subtidal rocky shore community at a marginal coral reef site at Búzios, about $300 \mathrm{~km}$ from Ilha Grande. The presence of the same abundant taxa as cited above by both studies would imply that similar communities are widespread throughout the tropical rocky shores of southeast Brazil.

The second outstanding question is that to tease apart and identify the specific interactions that occur between the receptor biota and invader, manipulative experimental approaches, such as the removal of Tubastraea spp. or density manipulation, are necessary. Dijkstra et al. (2007) compared the dominance and seasonal patterns of abundance of invasive colonial ascidians on rocky shores and showed that the high 
Table 2. Univariate descriptors of the rocky shore community based on percentage cover at 8 study sites at Ilha Grande Bay: species richness $(S)$, diversity (ShannonWiener index, $H^{\prime}$ ) and evenness (Pielou's index, $J^{\prime}$ ). The values in parentheses are the same indices recalculated on standardized data after discarding the cover values of the invasive corals Tubastraea spp.

\begin{tabular}{|lccc|}
\hline Sites & $S$ & $H^{\prime}$ & $J^{\prime}$ \\
\hline Abraãozinho & $17(17)$ & $0.94(0.94)$ & $0.33(0.33)$ \\
Aroeira & $21(19)$ & $1.67(1.41)$ & $0.55(0.48)$ \\
Barreto & $15(13)$ & $1.11(1.10)$ & $0.41(0.42)$ \\
Crena & $23(23)$ & $2.07(2.07)$ & $0.66(0.66)$ \\
Estrela & $14(13)$ & $1.07(1.00)$ & $0.40(0.39)$ \\
Guaxumã & $14(14)$ & $1.10(1.10)$ & $0.42(0.42)$ \\
Macacos & $17(15)$ & $1.53(1.36)$ & $0.54(0.50)$ \\
Saco do Céu & $21(20)$ & $1.94(1.93)$ & $0.63(0.64)$ \\
\hline
\end{tabular}

abundance of these ascidians during summer and fall could inhibit the recruitment and reduce the amount of space available for other species. In a study conducted by Blum et al. (2007) the non-native ascidian Ciona intestinalis depressed local species diversity and altered the community assembly processes, changing sessile community composition in San Francisco Bay, California, where it occurs in dense aggregations. We would learn a lot from using such approaches for Tubastraea spp. as well.

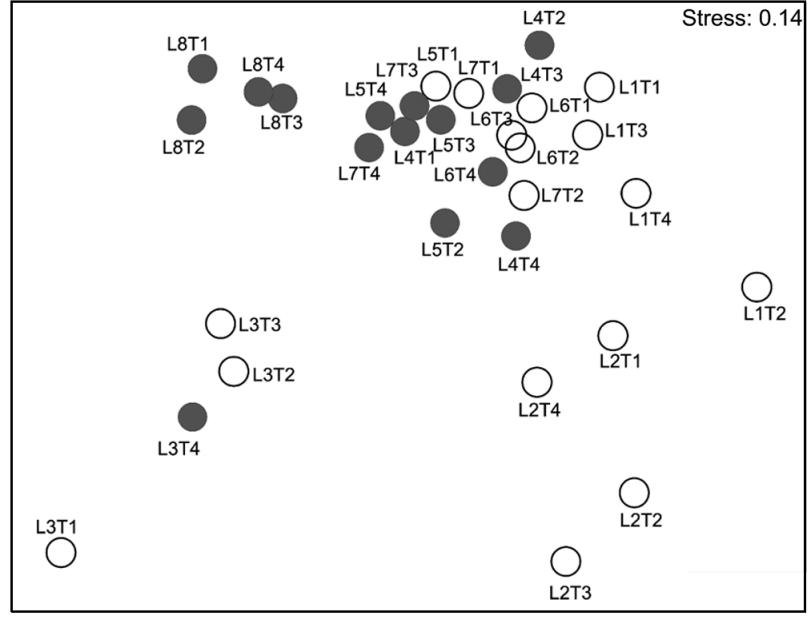

Fig. 6. Tubastraea spp. Community ordination. MDS analysis using random quadrat data for each site and time, highlighting those transects where Tubastraea spp. were present (๑) or absent (O). L1: Abraãozinho; L2: Crena; L3: Saco do Céu; L4: Estrela; L5: Barreto; L6: Guaxumã; L7: Macacos; L8: Aroeira site. T1: February 2005; T2: July 2005; T3: February 2006; T4: July 2006

Large invertebrates can have profound architectural importance in structuring ecosystems on both rocky and sediment bottoms (Olenin et al. 2007, Wallentinus \& Nyberg 2007). The effects of the abundance, distribution range and magnitude of alien species can also

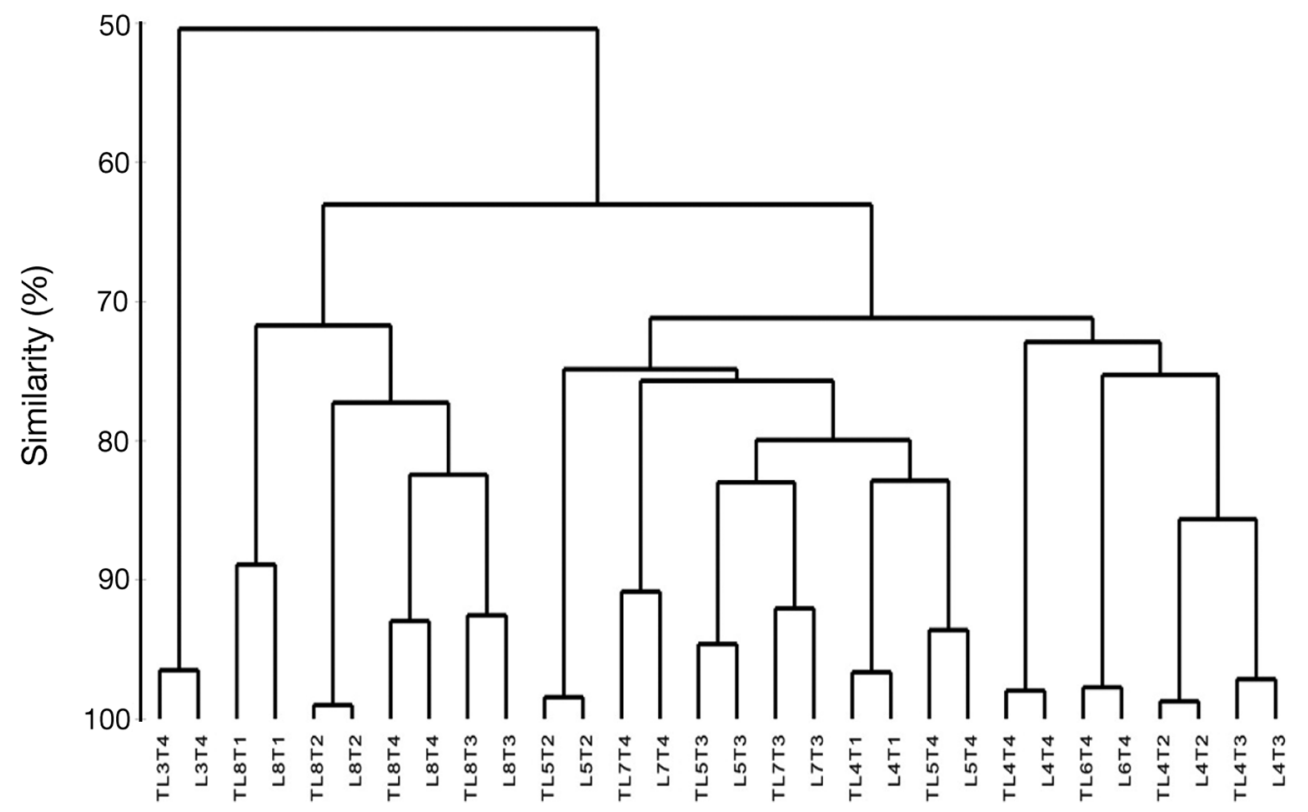

Fig. 7. Tubastraea spp. Community similarity. Cluster analysis using random quadrats data (site-time means) showing effects on similarity of the presence and absence of Tubastraea spp. in the communities. Prefix T: original communities where Tubastraea spp. were present. Without prefix T: communities where Tubastraea spp. was artificially excluded from the data before restandardizing. Lettering see legend of Fig. 6. Only sites and times where Tubastraea spp. were present were used in the analysis 


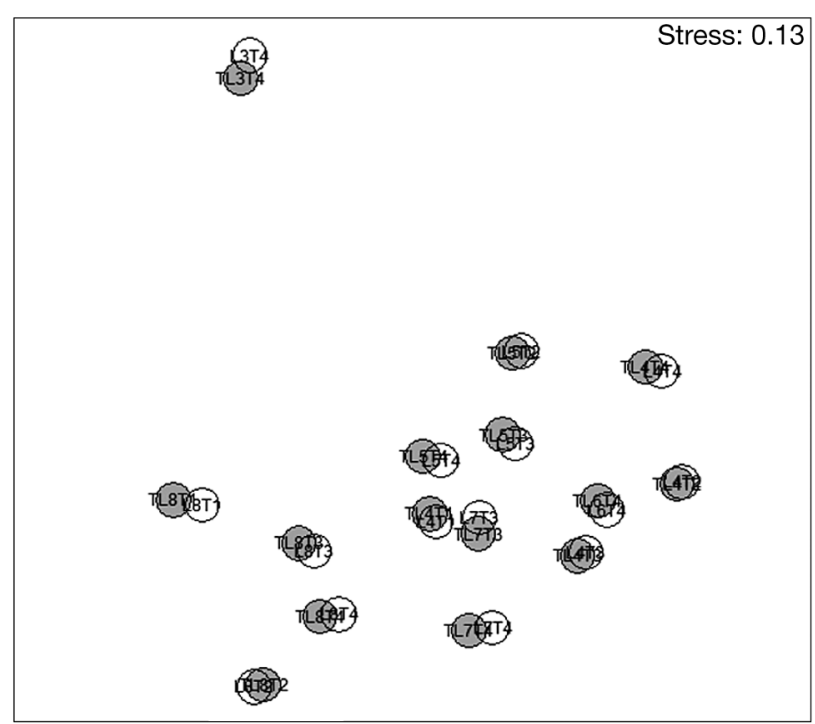

Fig. 8. Tubastraea spp. Community similarity. MDS analysis using random quadrats data (site-time means) showing effects on ordination of the presence and absence of Tubastraea spp. in the communities. O: original communities where Tubastraea spp. were present. O: communities where Tubastraea spp. were artificially excluded from the data before restandardizing. Lettering see legend of Fig. 6. Only sites and times where Tubastraea spp. were present were used in the analysis

vary over time (Olenin et al. 2007). Alien species may affect native species and communities through hybridization, competition with native species for resources (such as food, nutrients, light, space), grazing, predation or parasitism on native species, excretion, toxins and quantitative changes in community structure (Coll 1992, Maida et al. 1995, Ferreira et al. 2004, Lages et al. 2006, Olenin et al. 2006).

Although the presence of Tubastraea spp. increased species richness, evenness and diversity, one would predict that these indices will probably decrease as competitive interactions occur and abundances of competitors are reduced over the longer term. In addition, Tubastraea, at high abundances, may reduce the heterogeneity of habitat, which can result in a decrease in richness. Certainly it is not uncommon to see large areas dominated by Tubastraea spp. Some invasions have resulted in a net gain in the number of species present at the local or regional level, at least in the short term (Sax \& Gaines 2003), but invasive species are also believed to decrease drastically the biodiversity over the long term (Jousson et al. 2000, Meinesz et al. 2001, Chisholm \& Moulin 2003, Simberloff et al. 2005, Galil 2007, Wallentinus \& Nyberg 2007). Again, experimental approaches are needed.
Introductions of large space-occupying organisms may result in positive interactions and these corals, which can occur in extremely high densities, may provide shelter or increase habitat diversity and spatial heterogeneity as has been found in other habitats (Richardson et al. 2000, Bertness et al. 2001, Ricciardi 2001, Bruno et al. 2003, Tews et al. 2004, Wallentinus \& Nyberg 2007). Negative impacts may also occur owing to the increasing homogeneity of the environment when an alien species dominates the habitat (Melbourne et al. 2007). However, a few studies have contended that engineering alien species in coastal waters play a beneficial role in ecosystem functioning (Richardson et al. 2000, Ricciardi 2001, Sax \& Gaines 2003), while most others assume that invaders affect native biota negatively. Lages et al. (2010a) identified somewhat mixed effects of crude extracts of Tubastraea coccinea and T. tagusensis on potential predators and competitors. The study showed that significantly fewer algae (Cladophora sp. and Lithophyllum sp.) grew on treatment (extract) than on control plates. Moreover, the methanol extract of $T$. coccinea also reduced the palatability to generalist fish.

Ecological interactions among invading species are common and may be important in facilitating invasions (Duffy 2006). Indeed, the presence of one nonindigenous species can act as an agent of disturbance that facilitates additional invasions ('invasion meltdown') (Simberloff \& Halle 1999, Ricciardi 2001, Levin et al. 2002, Grosholz 2005). Tubastraea spp. possess chemical (Lages et al. 2010a,b) and reproductive attributes that aid in the expansion of the range of these exotic species throughout the region and erode the integrity of benthic communities. The disruption of resident native species and alteration of habitat may trigger favorable conditions for other invaders, thereby creating a positive feedback that accelerates new invasions of alien species and may result in substantial synergistic effects.

With regard to its invasion worldwide, the genus Tubastraea was initially reported invading the northwestern Atlantic Ocean in 1943, but at present species of this genus have expanded their range to the entire Caribbean region as well as the Atlantic, Indian and Pacific oceans (Fenner \& Banks 2004). New records of Tubastraea spp. confirm species of the genus to be successful invasive organisms and may be considered opportunists because of their rapid range expansion and rising abundance in newly colonized areas (Cairns 2000, Sammarco et al. 2010).

Tubastraea coccinea is probably the most widespread invasive alien coral reported to date and 
occurs on ship bottoms, dock pilings, buoys, oil platforms and other human-made objects (Cairns 2000, Fenner 2001, Fenner \& Banks 2004, Paula \& Creed 2004, Sammarco et al. 2004). This species has invaded the Gulf of Mexico, Florida and the Caribbean (Fenner \& Banks 2004) and is today considered cosmopolitan owing to its broad distribution. The native distribution of $T$. tagusensis has been described as restricted to the Galapagos Archipelago. In Brazil the species is exotic and has only been reported from the region where the study was carried out. Another species of the genus, T. micranthus, also from the IndoPacific region, has been reported from 1 oil production platform in the Gulf of Mexico but has not yet made the transition to the natural substratum (Sammarco et al. 2010) and does not yet occur in Brazil.

The success of Tubastraea coccinea and T. tagusensis as colonizers of newly available habitat has been attributed to their early reproductive age (Fenner \& Banks 2004, Glynn et al. 2008) and fast growth (Vermeij 2005). Moreover, the genus Tubastraea can produce planulae that can remain competent for up to 100 d (Ayre \& Resing 1986, Fenner 2001, Fenner \& Banks 2004, Glynn et al. 2008). These corals should be considered to be highly invasive and represent a significant threat to coral reefs and tropical rocky shore communities worldwide.

In the marine realm a double biological invasion by conspecific corals can be considered a rare event. Our study showed, for the first time, the effects of 2 species of Tubastraea spp. on community structure of tropical rocky shores in the southwest Atlantic Ocean. We conclude that the negative effects of these species are sufficient to disturb the native benthic communities throughout the tropical Atlantic with adverse consequences for the native communities in the long term. The rate of change is staggeringly quick and the information regarding rates of temporal change is of fundamental importance for models aimed at predicting further range expansion of the corals and providing for an effective control program to slow the spread of these noxious marine pests.

Acknowledgements. We thank L. Vidal and A. F. de Paula, B. Antunes, S. S. O. Pszczol and L. Souza (in memoriam) for assistance in the field. We thank 3 anonymous referees for their comments. We also thank the students and researchers that contributed to the present study with assistance in the lab and the Centro de Estudos Ambientais e Desenvolvimento Sustentável/UERJ (CEADS/UERJ) for the use of its staff and facilities. B.G.L. gratefully acknowledges Fundação Carlos Chagas Filho de Amparo à Pesquisa do Estado do Rio de Janeiro (FAPERJ) that provided a doctoral scholarship; J.C.C. acknowledges financial support from the
Programa de Incentivo à Produção Científica, Técnica e Artística, UERJ and Conselho Nacional de Desenvolvimento Científico e Tecnológico and a grant from the FAPERJ no. E-25/170669/2004, Coordenação de Aperfeiçoamento de Pessoal de Nível Superior (CAPES) 'Ciências do Mar' 1137/ 2010 and sponsorship from Petrobras through the Programa Petrobras Ambiental.

\section{LITERATURE CITED}

Ayre DJ, Resing JM (1986) Sexual and asexual production of planulae in reef corals. Mar Biol 90:187-190

Bertness M, Gaines SD, Hay M (2001) Marine community ecology. Sinauer Press, Sunderland, MA

Blum JC, Chang AL, Liljesthröm M, Schenk ME, Steinberg MK, Ruiz GM (2007) The non-native solitary ascidian Ciona intestinalis (L.) depresses species richness. J Exp Mar Biol Ecol 342:5-14

$>$ Bruno JF, Stachowicz JJ, Bertness MD (2003) Incorporating facilitation into ecological theory. Trends Ecol Evol 18: 119-125

$>$ Bush SL, Precht WF, Woodley JD, Bruno JF (2004) IndoPacific mushroom corals found on Jamaican reefs. Coral Reefs 23:234

Cairns SD (2000) A revision of the shallow-water azooxanthellate Scleractinia of the Western Atlantic. Stud Nat Hist Caribb 75:1-240

Carlton JT (1985) Transoceanic and interoceanic dispersal of coastal marine organisms: the biology of ballast water. Oceanogr Mar Biol Annu Rev 23:313-373

Carlton JT (1987) Patterns of transoceanic marine biological invasions in the Pacific Ocean. Bull Mar Sci 41:452-465

Carlton JT (1996) Pattern, process, and prediction in marine invasion ecology. Biol Conserv 78:97-106

Cariton JT [i.e. Carlton JT], Geller JB (1993) Ecological roulette: the global transport of nonindigenous marine organisms. Science 261:78-82

Castro CB, Pires DO (2001) Brazilian coral reefs: what we already know and what is still missing. Bull Mar Sci 69: 357-371

Castro CB, Echeverria CA, Pires DO, Fonseca CG (1999) Distribuição do bentos (Cnidaria e Echinodermata) em costões rochosos da Baía da Ilha Grande, Rio de Janeiro, Brasil. In: Silva SHG, Lavrado HP (eds) Oecologia Brasiliensis: ecologia dos ambientes costeiros do estado do Rio de Janeiro. Programa de Pós-Graduação em Ecologia - Universidade Federal do Rio de Janeiro (PPGEUFRJ), Rio de Janeiro

Chisholm JRM, Moulin P (2003) Stimulation of nitrogen fixation in refactory organic sediments by Caulerpa taxifolia (Chlorophyta). Limnol Oceanogr 48:787-794

$>$ Coll JC (1992) The chemistry and chemical ecology of octocorals (Coelenterata, Anthozoa, Octocorallia). Chem Rev 92:613-631

> Creed JC (2006) Two invasive alien azooxanthellate corals, Tubastraea coccinea and Tubastraea tagusensis, dominate the native zooxanthellate Mussismilia hispida in Brazil. Coral Reefs 25:350

Creed JC, Absalão RS, Brasil ACS, Figueiredo MAO and others (2007) Sumário executivo. In: Creed JC, Pires DO, Figueiredo MAO (eds) Biodiversidade marinha da Baia da Ilha Grande. Ministério do Meio Ambiente (MMA), Brasília

Dijkstra J, Harris LG, Westerman E (2007) Distribution and 
long-term temporal patterns of four invasive colonial ascidians in the Gulf of Maine. J Exp Mar Biol Ecol 342: 61-68

Duffy JE (2006) Biodiversity and the functioning of seagrass ecosystems. Mar Ecol Prog Ser 311:233-250

Eston VR, Migotto AE, Oliveira Filho EC, Rodrigues SA, Freitas JC (1986) Vertical distribution of benthic marine organisms on rocky coasts of Fernando de Noronha Archipelago (Brazil). Bolm Inst Oceanogr 34:37-53

Fenner D (2001) Biogeography of three Caribbean corals (Scleractinia) and the invasion of Tubastraea coccinea into the Gulf of Mexico. Bull Mar Sci 69:1175-1189

Fenner D, Banks K (2004) Orange cup coral Tubastraea coccinea invades Florida and the Flower Garden, northwestern Gulf of Mexico. Coral Reefs 23:505-507

Ferreira CEL (2003) Non-indigenous corals at marginal sites. Coral Reefs 22:498

Ferreira CEL, Gonçalves JEA, Coutinho R (2004) Ship hulls and oil platforms as potential vectors to marine species introduction. J Coast Res 39:1341-1346

Fine M, Zibrowius H, Loya Y (2001) Oculina patagonica: a non-lessepsian scleractinian coral invading the Mediterranean Sea. Mar Biol 138:1195-1203

Galil BS (2007) Loss or gain? Invasive aliens and biodiversity in the Mediterranean Sea. Mar Pollut Bull 55:314-322

Ghilardi NP, Pereira Filho GH, Berchez F (2008) Current knowledge status of the ecology of hard bottom benthic communities in Brazil and the need for new approach. Oecol Bras 12:197-205

Glynn PW, Colley SB, Maté JC, Guzman HM, Bailey RL, Feingold JS, Enochs IC (2008) Reproductive ecology of the azooxanthellate coral Tubastraea coccinea in the Equatorial Eastern Pacific: Part V. Dendrophyllidae. Mar Biol 153:529-544

Grigg RW (2003) Invasion of a deep water coral bed by an alien species, Carijoa riisei. Coral Reefs 22:121-122

- Grosholz ED (2002) Ecological and evolutionary consequences of coastal invasions. Trends Ecol Evol 17:22-27

Grosholz ED (2005) Recent biological invasion may hasten invasional meltdown by accelerating historical introductions. Proc Natl Acad Sci USA 102:1088-1091

Idjadi JA, Edmunds PJ (2006) Scleractinian corals as facilitators for other invertebrates on a Caribbean reef. Mar Ecol Prog Ser 319:117-127

> Jones CG, Lawton JH, Shachak M (1997) Positive and negative effects of organisms as physical ecosystem engineers. Ecology 78:1946-1957

> Jousson O, Pawlowski J, Zaninetti L, Zechman FW and others (2000) Invasive alga reaches California. Nature 408: $157-158$

Kahng SE, Grigg RW (2005) Impact of an alien octocoral, Carijoa riisei, on black corals in Hawaii. Coral Reefs 24: 556-562

Lages BG, Fleury BG, Ferreira CEL, Pereira RC (2006) Chemical defense of an exotic coral as invasion strategy. J Exp Mar Biol Ecol 328:127-135

Lages BG, Fleury BG, Pinto AC, Creed JC (2010a) Chemical defenses against generalist fish predators and fouling organisms in two invasive ahermatypic corals in the genus Tubastraea. PSZN I: Mar Ecol 31:473-482

Lages BG, Fleury BG, Rezende CM, Pinto AC, Creed JC (2010b) Chemical composition and release in situ due to injury of the invasive coral Tubastraea (Cnidaria, Scleractinia). Braz J Oceanogr 58:47-56

Levin PS, Coyer JA, Petrik R, Good TP (2002) Community- wide effects of nonindigenous species on temperate rocky reefs. Ecology 83:3182-3193

> Mack RN, Simberloff D, Londsdale WM, Evans H, Clout M, Bazzaz FA (2000) Biological invasions: causes, epidemiology, global consequences, and control. Ecol Appl 10: $689-710$

Magurran AE (1988) Ecological diversity and its measurement. Princeton University Press, Princeton, NJ

Maida M, Sammarco PW, Coll JC (1995) Preliminary evidence for directional allelopathic effects of the soft coral Sinularia flexibilis (Alcyonacea: Octocorallia) on scleractinian coral recruitment. Bull Mar Sci 56:303-311

Mantelatto MC, Creed JC, Mourão GG, Migotto AE, Lindner A (2011) Range expansion of the invasive corals Tubastraea coccinea and Tubastraea tagusensis in the Southwest Atlantic. Coral Reefs 30:397

> Meinesz A, Belsher T, Thibaut T, Antolic B and others (2001) The introduced alga Caulerpa taxifolia continues to spread in the Mediterranean. Biol Invasions 3:201-210

> Melbourne BA, Cornell HV, Davies KF, Dugaw CJ and others (2007) Invasion in a heterogeneous world: resistance, coexistence or hostile takeover? Ecol Lett 10:77-94

> Mills EL, Leach JH, Carlton JT, Secor CL (1994) Exotic species and the integrity of the Great Lakes: lessons from the past. Bioscience 44:666-676

Oigman-Pszczol SS, Creed JC (2004) Size structure and spatial distribution of the corals Mussismilia hispida and Siderastrea stellata (Scleractinia) at Armação dos Buzios, Brazil. Bull Mar Sci 74:433-448

Oigman-Pszczol SS, Figueiredo MAO, Creed JC (2004) Distribution of benthic communities on the tropical rocky subtidal of Armação dos Búzios, Southeastern Brazil. PSZN I: Mar Ecol 25:173-190

Olenin S, Daunys D, Leppäkoski E, Zaiko A (2006) Baltic Sea alien species database. www.corpi.ku.lt/nemo (accessed March 2009)

> Olenin S, Minchin D, Daunys D (2007) Assessment of biopollution in aquatic ecosystems. Mar Pollut Bull 55:379-394

Paula AF, Creed JC (2004) Two species of the coral Tubastraea (Cnidaria, Scleractinia) in Brazil: a case of accidental introduction. Bull Mar Sci 74:175-183

Paula AF, Creed JC (2005) Spatial distribution and abundance of nonindigenous coral genus Tubastraea (Cnidaria, Scleractinia) around Ilha Grande, Brazil. Braz J Biol 65:661-673

> Pimentel D, Zuniga R, Morrison D (2005) Update on the environmental and economic costs associated with alieninvasive species in the United States. Ecol Econ 52: 273-288

> Ricciardi A (2001) Facilitative interactions among aquatic invaders: Is an 'invasional meltdown' occurring in the Great Lakes? Can J Fish Aquat Sci 58:2513-2525

> Richardson DM, Pyšek P, Rejmánek M, Barbour MG, Panetta FD, West CJ (2000) Naturalization and invasion of alien plants: concepts and definitions. Divers Distrib 6: 93-107

Sammarco PW, Atchison AD, Boland GS (2004) Expansion of coral communities within the northern Gulf of Mexico via offshore oil and gas platforms. Mar Ecol Prog Ser 280: 129-143

Sammarco PW, Porter SA, Cairns SD (2010) New invasive coral species for the Atlantic Ocean: Tubastraea micranthus (Cairns and Zibrowius 1997) (Coelenterata, Anthozoa, Scleractinia): a potential major threat? Aquat Invasions 5:131-140 
Sartoretto S, Harmelin JG, Bachet F, Bejaoui N, Lebrun O, Zibrowius H (2008) The alien coral Oculina patagonica De Angelis, 1908 (Cnidaria, Scleractinia) in Algeria and Tunisia. Aquat Invasions 3:173-180

Sax DF, Gaines SD (2003) Species diversity: from global decreases to local increases. Trends Ecol Evol 18: 561-566

Simberloff D, Halle MV (1999) Synergistic interactions of nonindigenous species: invasional meltdown? Biol Invasions 1:21-32

Simberloff D, Parker IM, Windle PN (2005) Introduced species policy, management, and future research needs. Front Ecol Environ 3:12-20

Tews J, Moloney K, Jeltsch F (2004) Modeling seed dispersal

Editorial responsibility: Charles Birkeland,

Honolulu, Hawaii, USA in a variable environment: a case study of the fleshyfruited savanna shrub Grewia flava. Ecol Model 175: 65-76

$>$ Vermeij MA (2005) A novel growth strategy allows Tubastraea coccinea to escape small-scale adverse conditions and start over again. Coral Reefs 24:442

Villaça R, Pitombo FB (1997) Benthic communities of shallow-water reefs of Abrolhos, Brazil. Rev Bras Oceanogr 45:35-43

Wallentinus I, Nyberg CD (2007) Introduced marine organisms as habitat modifiers. Mar Pollut Bull 55:323-332

- Wilcove DS, Rothstein D, Dubow J, Phillips A, Losos E (1998) Quantifying threats to imperiled species in the United States. Bioscience 48:607-615

Submitted: May 6, 2011; Accepted: July 8, 2011

Proofs received from author(s): September 12, 2011 